\title{
Tratamiento y complicaciones de las fracturas de seno frontal
}

\author{
Frontal sinus fracture treatment and complications
}

\author{
S. Heredero Jung', I. Zubillaga Rodríguez², M. Castrillo Tambay, G. Sánchez Aniceto², \\ J.J. Montalvo Moreno ${ }^{3}$
}

Resumen: Introducción. Las fracturas de seno frontal se producen como resultado de impactos de alta energía. Un tratamiento inadecuado puede conducir a complicaciones serias incluso muchos años después del traumatismo. Objetivos. Evaluar los datos epidemiológicos y revisar las complicaciones asociadas. Estandarizar el protocolo de tratamiento. Materiales y métodos. Se revisaron 95 pacientes diagnosticados de fracturas de seno frontal pertenecientes al servicio de Cirugía Oral y Maxilofacial del Hospital Universitario 12 de Octubre de Madrid, entre enero de 1990 y diciembre de 2004. Resultados. La edad media de los pacientes revisados es de 34 años. La mayoría son hombres (78\%) y la causa más frecuente del traumatismo, los accidentes de tráfico. El patrón de fractura más común es el que afecta únicamente a la pared anterior del seno frontal. Las complicaciones descritas son: deformidad estética frontal, sinusitis frontal, mucocele frontal, celulitis fronto-orbitaria, intolerancia al material de osteosíntesis, complicaciones infecciosas del SNC y persistencia de fístula de líquido cefalorraquídeo. Conclusiones. El objetivo ha de estar encaminado a prevenir las complicaciones asociadas a los pacientes con fracturas de seno frontal. Hay que individualizar el protocolo de tratamiento en cada caso. Es recomendable un seguimiento a largo plazo para identificar precozmente las posibles complicaciones.

Palabras clave: Fracturas de seno frontal; Obliteración; Cranealización; Abordaje subcraneal.

Recibido: 20.09.05

Aceptado: 18.12 .05

1 Médico Residente.

2 Médico Adjunto.

3 Jefe de Servicio.

Servicio de Cirugía Oral y Maxilofacial.

Hospital Universitario 12 de Octubre, Madrid, España

Correspondencia:

Susana Heredero Jung

Hospital Universitario 12 de Octubre

Servicio de Cirugía Oral y Maxilofacial

Avenida de Córdoba s/n

28041 Madrid, España

Email: susana_heredero@yahoo.es
Abstract: Introduction. Frontal sinus fractures are caused by high velocity impacts. Inappropriate treatment can lead to serious complications, even many years after the trauma. Objectives. To evaluate epidemiological data and associated complications. To standardize the treatment protocol. Materials and methods. the clinical records of 95 patients with frontal sinus fractures treated between January 1990 and December 2004 at the Oral and Maxillofacial Surgery Department, "12 de Octubre" Hospital (Madrid, Spain), were reviewed. Results. The average age of patients with frontal sinus fractures was 34 years. Most of them were male (78\%) and the most frequent mode of injury was motor vehicle accident. The commonest frontal sinus fracture pattern was the outer table fracture. The complications described were: cosmetic deformation, frontal sinusitis, frontal mucocele, orbital cellulitis, intolerance of osteosynthesis material, meningitis and persistent CSF leak. Conclusions. Treatment of frontal sinus fractures must be tailored for each individual patient. Its aim should be to reduce associated complications, which may need a long-term follow-up to be detected.

Key words: Frontal sinus fractures; Obliteration; Cranialization; Subcranial approach. 


\section{Introducción}

Las fracturas de seno frontal son relativamente poco frecuentes, representando en las distintas series de un 2 a un $15 \%$ de las fracturas faciales ${ }^{1,2}$ y con una incidencia en nuestro medio de un $3,15 \%{ }^{3}$

Los senos frontales, ausentes en el nacimiento, comienzan a desarrollarse a partir de los 2 años de edad, derivados de una evaginación de las celdillas etmoidales infundibulares del receso frontal. No se observan radiológicamente hasta los 8 años y no alcanzan el tamaño adulto hasta a partir de los 12 . En un $4 \%$ de las personas están ausentes, en un $5 \%$ son unilaterales y en un $10 \%$ son asimétricos. Drenan hacia los meatos medios a través de los denominados conductos nasofrontales, que se localizan en la región posteromedial del suelo sinusal. Hasta en el $85 \%$ de las personas no son conductos como tales, sino unos simples orificios de drenaje. 4

El volumen medio del seno frontal adulto es de unos $5 \mathrm{~cm}^{3}$. Los senos frontales limitan posteriormente con la lámina cribiforme, la duramadre y los lóbulos frontales. Inferiormente, con el techo orbitario. Interiormente están recubiertos por la mucosa sinusal, que se continúa con la de las celdillas etmoidales y la de los conductos nasofrontales. Esta mucosa se caracteriza por la presencia de los nidos vasculares de Breschet, puntos de drenaje venoso que, por una parte, pueden provocar diseminación intracraneal de infecciones y por otra, pueden conducir a la formación de mucoceles si la mucosa que los recubre no se elimina adecuadamente. ${ }^{5}$

Las fracturas de seno frontal se producen como resultado de impactos de alta energía, por lo que es frecuente observarse en pacientes politraumatizados y con otras fracturas faciales. Existen numerosas clasificaciones propuestas para las fracturas de seno frontal, $, 5,6$ pero en general puede decirse que es fundamental valorar la afectación de la pared posterior y/o del conducto nasofrontal.

El tratamiento de las fracturas de seno frontal es controvertido, no existiendo un único algoritmo terapéutico. Además, es importante considerar que un tratamiento inadecuado de estas fracturas puede conducir a serias complicaciones, principalmente de tipo infeccioso, incluso muchos años después del traumatismo.

Este trabajo tiene por objeto evaluar los datos epidemiológicos y los patrones clínico-radiológicos correspondientes a las fracturas de seno frontal analizadas, así como revisar las complicaciones asociadas y estandarizar el protocolo de manejo terapéutico.

\section{Material y método}

En este estudio se revisaron 95 pacientes diagnosticados de fracturas de seno frontal y que además precisaron ingreso hospitalario en el servicio de Cirugía Oral Maxilofacial del Hospital Universitario 12 de Octubre de Madrid, entre enero de 1990 y diciembre de 2004. Se incluyeron 86 pacientes, aquellos con un registro clínico-radiológico completo de su evolución y con un tiempo mínimo de seguimiento de 6 meses. El seguimiento medio para el total de la serie fue de 29 meses. Se realizaron revisiones periódicas con TC de control a los 6, 12 y 24 meses. El programa informático de estadística utilizado fue el SPSS 11,5 (SPSS Inc., Chicago, Illinois, EE.UU.).

\section{Introduction}

Frontal sinus fractures are relatively rare and they represent 2 to $15 \%$ of all facial fractures 1,2 in the various series, and in our sector the incidence rate is $3.15 \%{ }^{3}$

The frontal sinuses, which are absent at birth, begin to develop as from the age of two, as a result of the outpouching of infundibular ethmoidal cells of the frontal recess. They cannot be observed radiologically until the age of eight, and they do not reach adult size until the age of 12 . In $4 \%$ of people they are absent, in 5\% they are unilateral and in 10\% they are asymmetric. They drain towards the middle meatus through the so-called nasofrontal ducts that are located in the posteromedial region of the sinus floor. In as many as $85 \%$ of people these are not ducts as such, but simple drainage orifices. ${ }^{4}$

The mean volume of the adult frontal sinus is around $5 \mathrm{~cm}^{3}$. The posterior boundary of the frontal sinus meets the cribriform plate, the duramater and the frontal lobes. Its lower boundary meets the orbital roof. They are covered on the inside with sinus mucosa, and then with ethmoidal cells and the nasofrontal ducts. The mucosa has Breschet's characteristic vascular pits, together with venous drainage points, which on the one hand can lead to intracranial dissemination of infections, and on the other to mucocele formation, if the mucosa covering them is not eliminated adequately. ${ }^{5}$

Nasofrontal fractures arise as a result of high-energy impacts, and they are frequently observed in polytraumatized patients and in other facial fractures. Numerous classifications have been proposed for frontal sinus fractures,, 5 but in general it can be said that evaluating any posterior table involvement, or of the nasofrontal duct, is fundamental.

Frontal sinus fracture treatment is controversial, as there is no single therapeutic algorithm. In addition, it is important to bear in mind that inadequate treatment of these fractures can lead to serious complications, principally of the infectious type, many years even after treatment.

The aim of this paper is to evaluate the epidemiological data and the clinico-radiological patterns corresponding to the analysis of frontal sinus fractures, as well as to review the associated complications, and the standardization of therapeutic management.

\section{Material and method}

In this study, 95 patients are reviewed who were diagnosed with fractures of the frontal sinus and who, in addition, required treatment on an in-patient basis by the department of Maxillofacial Surgery of the Hospital Universitario 12 de Octubre in Madrid, between January 1990 and December 2004. 86 patients were included in the study. They all had complete clinical and radiological reports and they had been followed for a minimum of 6 months. The mean fol- 


\section{Resultados}

Entre los pacientes incluidos en el estudio se observa un claro predominio masculino (78\%). La muestra presenta una distribución de edades que no es estrictamente gaussiana (Fig. 1). Así, la mayoría de los individuos posee entre 20-30 años y además existe una agrupación de los pacientes alrededor de los 40-50 años.

En la tabla 1 se describen las características sobre la etiología y mecanismo del traumatismo, así como las lesiones asociadas en el momento del ingreso. Los accidentes de tráfico fueron la causa más frecuente del traumatismo en la muestra estudiada (57\%). El mecanismo de producción de las fracturas de seno frontal observado en la mayoría de los pacientes fue el impacto directo (88\%).

El patrón de fractura más comúnmente hallado fue el que incluye únicamente a la pared anterior del seno frontal, observado en más de la mitad de la serie. En concreto, las más frecuentes fueron las fracturas que implican un hundimiento unilateral. Por otra parte, la mayoría de fracturas con afectación unilateral de paredes anterior y posterior del seno frontal fueron fracturas desplazadas. Por último, una minoría de pacientes presentó fracturas con afectación de paredes anteriores y posteriores de ambos senos frontales, siendo éstos casos de traumatismos de muy alta energía, con frecuente conminución y asociación de otras fracturas faciales.

Respecto a otras lesiones observadas en pacientes con fracturas de seno frontal, es importante señalar que 38 de ellos son en realidad politraumatizados $(44,2 \%)$. Por lo tanto, es habitual la asociación con otros traumatismos. Entre las lesiones más frecuentemente relacionadas se encuentran los traumatismos faciales, principalmente las fracturas que afectan al complejo nasoetmoidorbiatario, seguidas de las orbitomalares. Además hay que considerar la importante asociación con lesiones neuroquirúrgicas, observadas en la mitad de los pacientes, que pueden ser potencialmente graves. Exceptuando el traumatismo craneoencefálico, el hallazgo neuroquirúrgico más frecuente es el neumoencéfalo (Fig. 2).

El tratamiento quirúrgico fue indicado en 45 de pacientes. La incisión utilizada fue la bicoronal en la mayoría de los casos (n = 34), aunque en 10 pacientes el abordaje se realizó a través de las heridas faciales y en uno se hizo una incisión de blefaroplastia superior (para una mujer de 65 años con fractura-hundimiento no conminuta unilateral de pared anterior). La fijación tras la reducción se realizó en la mayoría de los casos con miniplacas de titanio de bajo perfil ( 1,3 y $1,0 \mathrm{~mm}$ ), si bien se utilizaron placas reabsorbibles en 4 pacientes de 7, 14, 27 y 29, todos ellos con fractura hundimiento unilateral no conminuta de pared anterior de seno frontal. En 7 pacientes se cranealizó uno o ambos senos fron- low-up for all the series was 29 months. Periodic monitoring was carried out with CAT scans at 6, 12 and 24 months. The software program used for the statistics was the SPSS 11.5 (SPSS Inc., Chicago, Illinois).

\section{Results}

With regard to the patients included in the study, there was a clear male predominance (78\%). The sample shows an age distribution that is not strictly Gaussian (Fig. 1). Most of the individuals were between the ages of 20-30 and, in addition there was a group of patients in the 40-50 age range.

In table 1 the characteristics regarding etiology and trauma mechanism are described, as well as associated lesions on admittance. Traffic accidents were the most common cause of trauma in the study sample (57\%). The mechanism producing the frontal sinus fractures was, in most patients, direct impact (88\%).

The most common fracture pattern included only the anterior table of the frontal sinus, and this was observed in more than half the patients in the series. The more common fractures were those that specifically included unilateral depression. Moreover, most fractures with unilateral involvement of the anterior and posterior tables of the frontal sinus were displaced fractures. Lastly, a minority of the patients had fractures that affected the anterior and posterior tables of both frontal sinuses, caused by high-energy impacts, and these were frequently comminuted and associated with other facial fractures.

With regard to other lesions observed in patients with fractures of the frontal sinus, it is important to stress that 38 of these were in reality polytraumatized patients (44.2\%). Therefore, the association with other types of trauma was common. The more common associated lesions included facial trauma, mainly fractures affecting the naso-orbitalethmoid complex, followed by orbito-malar fractures. In addition, the considerable association of neurosurgical lesions, observed in $50 \%$ of patients, and that can potentially be serious, should be taken into consideration. With the exception of craniocerebral trauma, the most common neurosurgical finding was pneumoencephalus (Fig. 2).

Forty-five patients required surgical treatment. A bicoronal incision was used in most cases $(n=34)$, although the 
Tabla 1. Resultados: Estadística descriptiva. Datos sobre etiología y mecanismo del traumatismo, así como lesiones asociadas a las fracturas del seno frontal. Se muestran porcentajes sobre el total de 86 pacientes.

\begin{tabular}{|c|c|c|}
\hline & $N$ & $\%$ \\
\hline \multicolumn{3}{|l|}{ ETIOLOGÍA } \\
\hline Accidente de tráfico & 49 & 57 \\
\hline Agresión & 13 & 15 \\
\hline Accidente laboral & 11 & 13 \\
\hline Accidente deportivo & 6 & 7 \\
\hline Contusión o caída accidental & 6 & 7 \\
\hline Autolesión (intento de suicidio) & 1 & 1 \\
\hline \multicolumn{3}{|l|}{ ETIOPATOGENIA } \\
\hline Impacto directo & 76 & 88 \\
\hline Precipitación & 5 & 6 \\
\hline Arma blanca & 2 & 2 \\
\hline Estallido & 1 & 1 \\
\hline Otros & 2 & 2 \\
\hline \multicolumn{3}{|l|}{ PATRÓN DE FRACTURA } \\
\hline Pared anterior de seno frontal & 53 & 62 \\
\hline Lineal unilateral & 16 & 19 \\
\hline Hundimiento unilateral & 28 & 33 \\
\hline Lineal bilateral & 3 & 3 \\
\hline Hundimiento bilateral & 6 & 7 \\
\hline Paredes anterior y posterior (unilateral) & 18 & 21 \\
\hline Sin desplazamiento & 5 & 6 \\
\hline Con desplazamiento & 13 & 15 \\
\hline Paredes anterior y posterior (bilateral) & 8 & 9 \\
\hline Otro & 7 & 8 \\
\hline \multicolumn{3}{|l|}{ LESIONES ASOCIADAS } \\
\hline Traumatismos faciales & 56 & 65 \\
\hline Fractura mandibular & 16 & 19 \\
\hline Fractura de suelo orbitario & 6 & 7 \\
\hline Fractura de pared medial orbitaria & 12 & 14 \\
\hline Lefort & 15 & 17 \\
\hline Fractura malar & 27 & 31 \\
\hline Fractura huesos propios nasales & 21 & 24 \\
\hline Fractura nasoetmoidorbitaria & 31 & 36 \\
\hline Lesiones neuroquirúrgicas & 43 & 50 \\
\hline Hematoma epidural & 3 & 3 \\
\hline Fístula de líquido cefalorraquídeo & 5 & 6 \\
\hline Traumatismo craneal grave & 5 & 6 \\
\hline Contunsión frontal & 10 & 12 \\
\hline Fractura craneal & 12 & 14 \\
\hline Neumoencéfalo & 24 & 28 \\
\hline Traumatismos oculares & 19 & 22 \\
\hline Perforación globo ocular & 7 & 8 \\
\hline Neuropatía óptica & 5 & 6 \\
\hline Traumatismos ortopédicos & 18 & 21 \\
\hline Traumatismos torácicos & 10 & 12 \\
\hline Traumatismo abdominal grave & 2 & 2 \\
\hline
\end{tabular}

Table 1. Results: Descriptive statistics. Data on etiology and trauma mechanism, as well as lesions associated with frontal sinus fractures. Percentages regarding all 86 patients are shown.

$\begin{array}{lcc} & N & \% \\ \text { ETIOLOGY } & & \\ \quad \text { Traffic accident } & 49 & 57 \\ \text { Aggression } & 13 & 15 \\ \text { Accident at work } & 11 & 13 \\ \text { Sports accident } & 6 & 7 \\ \text { Bruising or accidental fall } & 6 & 7 \\ \text { Self-inflicted lesion(suicide attempt) } & 1 & 1 \\ & & \\ \text { ETIOPATHOGENY } & & \\ \text { Direct impact } & 76 & 88 \\ \text { Fall } & 5 & 6 \\ \text { Sharp weapon } & 2 & 2 \\ \text { Explosion } & 1 & 1 \\ \text { Others } & 2 & 2\end{array}$

FRACTURE PATTERN

Anterior wall of frontal sinus $\quad 53 \quad 62$

Unilateral line $\quad 16 \quad 19$

Unilateral depression $\quad 28 \quad 33$

Bilateral line $\quad 3 \quad 3$

Bilateral depression $\quad 6 \quad 7$

Anterior and posterior (unilateral) walls $\quad 18 \quad 21$

Without displacement $\quad 5 \quad 6$

$\begin{array}{lll}\text { With displacement } & 13 & 15\end{array}$

$\begin{array}{lll}\text { Anterior and posterior (bilateral)walls } & 8 & 9 \\ \text { Others } & 7 & 8\end{array}$

\section{ASSOCIATED LESIONS}

$\begin{array}{lll}\text { Facial Trauma } & 56 & 65\end{array}$

Mandibular fracture $\quad 16 \quad 19$

$\begin{array}{lll}\text { Orbital wall fracture } & 6 & 7\end{array}$

Fracture of medial wall of orbit $\quad 12 \quad 14$

$\begin{array}{lll}\text { Lefort } & 15 & 17\end{array}$

$\begin{array}{lll}\text { Malar fracture } & 27 & 31\end{array}$

$\begin{array}{lll}\text { Fracture of bones of nose itself } & 21 & 24\end{array}$

Naso-orbital-ethmoid fracture $\quad 31 \quad 36$

Neurosurgical lesions $\quad 43 \quad 50$

Epidural hematoma 33

Cephalorrhachidian liquid fistula $\quad 5 \quad 6$

Serious skull trauma $\quad 5 \quad 6$

Frontal bruising $\quad 10 \quad 12$

$\begin{array}{lll}\text { Skull fracture } & 12 & 14\end{array}$

Pneumoencephalus $\quad 24 \quad 28$

Ocular trauma $\quad 19 \quad 22$

Perforation of eyeball $\quad 7 \quad 8$

Optic neuropathy $\quad 5 \quad 6$

$\begin{array}{lll}\text { Orthopedic trauma } & 18 & 21\end{array}$

Thoracic trauma $\quad 10 \quad 12$

Serious abdominal trauma $\quad 2 \quad 2$

tales. En 5 casos se obliteró uno de los senos frontales y en otros 5, ambos. La obliteración de los conductos nasofrontales y de los senos frontales se realizó con hueso autólogo de calota y colgajo de gálea-pericráneo. approach was made through facial wounds in ten patients, and in one an upper blepharoplasty incision was made (in a 65 year-old female with a unilateral depressed fracture of the anterior table that was not comminuted). The fixa- 
De todos los pacientes revisados, se han registrado complicaciones en 14 pacientes, lo que supone un $16,4 \%$ de los mismos. El 38,46\% de estas complicaciones fueron tardías, es decir, después de los 6 primeros meses tras el traumatismo. La complicación más frecuentemente observada fue la deformidad estética frontal: 6 pacientes presentaron una secuela leve que en ningún casó conllevó la necesidad de corrección quirúrgica posterior. Respecto a las complicaciones de tipo infeccioso local, 2 pacientes desarrollaron sinusitis frontales de repetición, 2 pacientes presentaron un mucoceles frontales $y$ otro paciente desarrolló una celulitis fronto-orbitaria que se resolvió espontáneamente. Además, se observó fístula de líquido cefalorraquídeo persistente en 5 pacientes, que se resolvió espontáneamente en todos ellos excepto en uno, en el que se optó por cranealizar el seno, solucionándose la complicación. Por último, sólo en uno de los pacientes se observó intolerancia al material de osteosíntesis, que tuvo que ser retirado.

\section{Discusión}

Los datos epidemiológicos observados coinciden con otras series anterior-

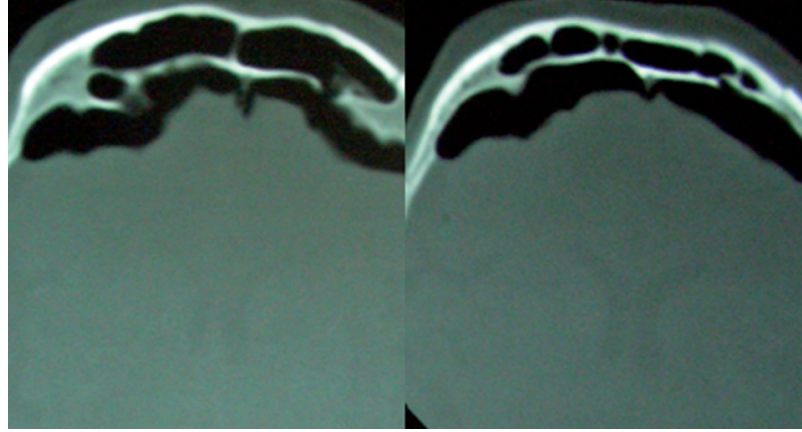
ambas paredes de los senos frontales.

Figure 2. Pneumoencephalus in patient with linear fracture of both frontal sinus walls.

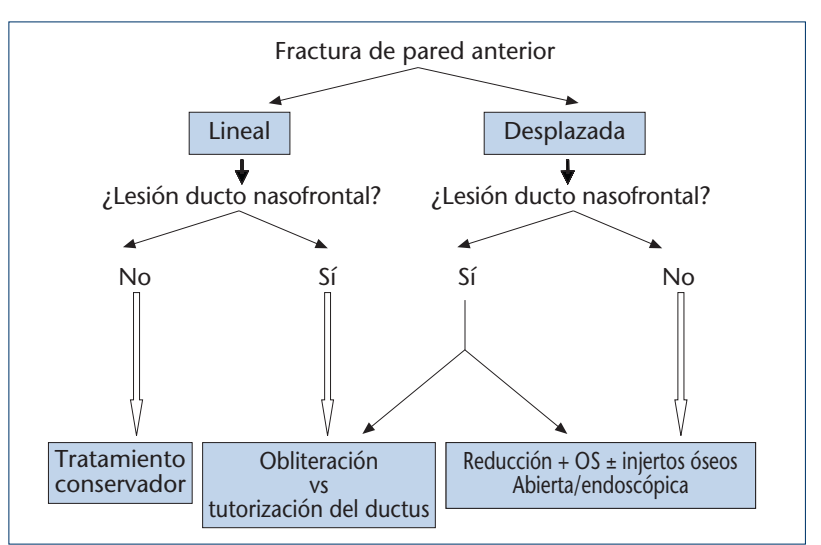

Figura 3. Algoritmo de tratamiento de las fracturas de seno frontal con afectación de la pared anterior (OS = osteosíntesis).

Figure 3. Treatment algorithm of frontal sinus fractures with anterior table involvement (OS = osteosynthesis).
Figura 2. Neumoencéfalo en paciente con fracturas lineales de

tion after reduction was carried out in most cases with low-profile titanium miniplates $(1.3$ and $1.0 \mathrm{~mm})$, although resorbable plates were used in 4 patients of 7 , 14, 27 and 29, all with unilateral depressed fractures of the anterior table of the frontal sinus that were not comminuted. In 7 patients either one sinus or both frontal sinuses were cranialized. In 5 cases one of the frontal sinuses was obliterated and in another 5 both were obliterated. The obliteration of the nasofrontal ducts and the frontal sinuses was carried out with autologous calvarial bone and a galeopericranial flap. Of all the patients reviewed, complications were registered in 14 patients or in $16.4 \%$. Of these complications $38.46 \%$ were delayed, that is to say, they appeared after the first 6 months following the trauma. The most common complication observed was aesthetic deformity in the frontal region: 6 patients had slight sequelae, and in no case was po de paciente un varón joven tras accidente de tráfico. Respecto a los patrones de fractura hallados, es importante mencionar que es posible que se pierda un porcentaje de pacientes con fracturas lineales aisladas de la pared anterior del seno frontal, puesto que pueden no haber precisado ingreso hospitalario. Por otra parte, es importante señalar que la asociación epidemiológica con otros traumatismos, que pueden ser graves, implica la necesidad de un abordaje multidisciplinar. Además, lesiones asociadas de tipo neuroquirúrgico u oftalmológico (compresión del nervio óptico) pueden condicionar la necesidad de un tratamiento quirúrgico urgente.

Ante un paciente con fractura de seno frontal, tal y como propuso lonnides en $1993,{ }^{9}$ los objetivos que deben plantearse en el momento de planificar el tratamiento son:

1. Aislamiento adecuado de la fosa craneal anterior y reparación de la fístula de líquido cefalorraquídeo si hubiese.

2. Prevenir las posibles complicaciones de tipo infeccioso asociadas a las fracturas de seno frontal.

3. Restaurar el aspecto estético previo al traumatismo.

Para ello, el algoritmo de tratamiento que proponemos para las fracturas de pared anterior se esquematiza en la figura 3. Las frac- posterior surgical correction required. With regard to local complications of an infectious type, two patients developed recurrent frontal sinusitis, two patients had frontal sinus mucocele and another patient developed fronto-orbital celIulitis that resolved spontaneously. In addition, a persistent fistula of cephalorrhaquidean liquid was observed in five patients, which resolved spontaneously in all of the patients except one, upon which a decision was made to cranialize the sinus, which solved the complication. Lastly, only in one patient was intolerance to osteosynthesis material, which required removal, observed.

\section{Discussion}

The epidemiological data observed coincide with other series previously published 7 , with the patient prototype being a young male following a traffic accident. With regard to the fracture patterns found, it is important to mention that it is possible for a percentage of patients with isolated linear 
turas de la pared anterior lineales que no asocian lesión del conducto nasofrontal se pueden manejar sin intervenir quirúrgicamente. Esta mismo se hizo en casos de fracturas levemente desplazadas en las que la secuela estética previsible era mínima y en pacientes que electivamente optaron por esta actitud. Cuando se sospecha lesión del conducto nasofrontal puede optarse por obliterar conducto y seno, o bien intentar dejarlo funcional mediante su tutorización. En la obliteración de los senos frontales, antes de reducir y fijar los fragmentos óseos, es fundamental resecar absolutamente toda la mucosa de dichos fragmentos, del conducto y del seno, y asimismo es recomendable fresar las paredes sinusales para eliminar la mucosa que pueda quedar en los nidos vasculares de Breschet. Se han propuesto distintos materiales para la obliteración con resultado satisfactorios, tanto autólogos, ${ }^{10}$ como sintéticos. Entre los materiales autólogos (grasa, músculo, hueso), la viruta ósea de calota (Fig. 4) presenta como ventajas una fácil obtención, la posibilidad de combinarse con otros materiales aloplásticos y de permitir un seguimiento radiológico adecuado con TC, ya que al presentar densidad ósea en la imagen radiológica facilita la detección precoz de complicaciones tales como mucoceles, fístulas o abscesos.

Por otra parte, como alternativa a la obliteración algunos autores abogan por preservar la funcionalidad del seno, con objeto de minimizar la incidencia de complicaciones infecciosas. Para ello recuren a la tutorización del conducto

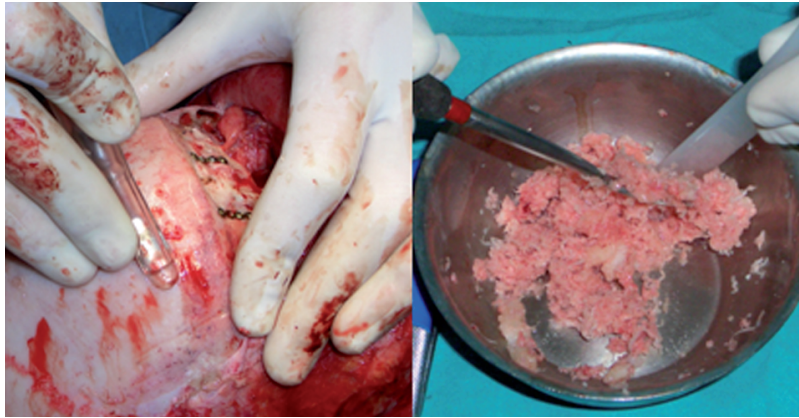

Figura 4. Obtención de viruta ósea de calota mediante la utilización de un rascador de hueso (Autogenus ${ }^{\circledR}$ ).

Figure 4. Calvarial bone chip obtained by means of using a bone scraper $\left(\right.$ Autogenus $\left.{ }^{\circledR}\right)$.

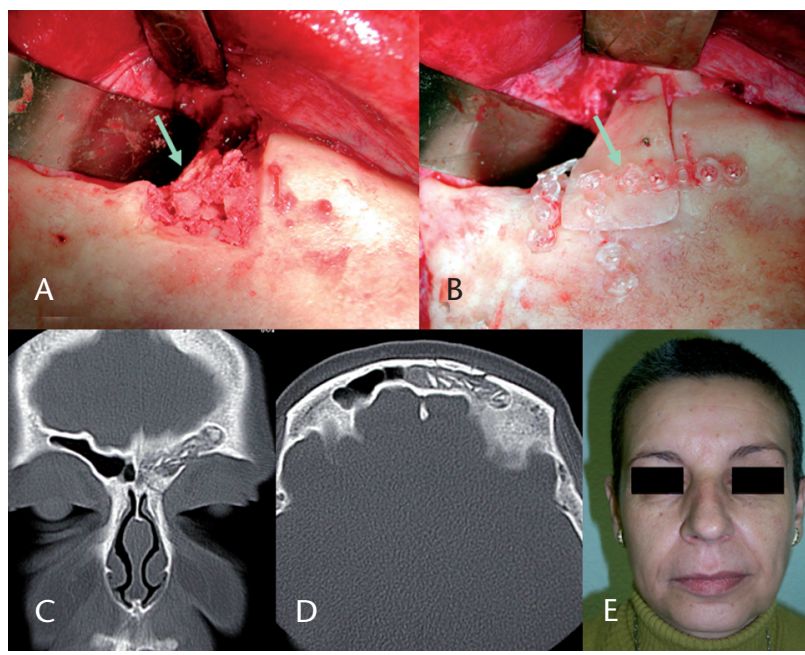

Figura 5. Abordaje subcraneal para tratamiento de mucocele postraumático: A) obliteración del seno con hueso autólogo de calota; B) reposición de la pared anterior y osteosíntesis con material reabsorbible; C) y D) TC postoperatorio; E) aspecto postoperatorio de la paciente.

Figure 5. Subcranial approach for post-trauma mucocele treatment: A) obliteration of the sinus with autologous calvarial bone; B) anterior table replacement and osteosynthesis with resorbable material; C) and D) postoperative (T scan; E) postoperative appearance of patient. fractures of the anterior table of the frontal sinus to be lost, as admittance may not have been required. On the other hand, it is important to point out that the epidemiological association with other traumas that may be serious, implies the need for a multidisciplinary approach. In addition, lesions of a neurosurgical or ophthalmologic nature (compression of the optic nerve) can condition the need for urgent surgical treatment.

The objectives when planning treatment for a patient with a fracture of the frontal sinus, as proposed by lonnides ${ }^{9}$ in 1993, should be:

1. Appropriate isolation of the anterior cranial fossa and repair of any CSF fistula.

2. Prevention of any possible complications of an infectious nature associated with the frontal sinus fracture.

3. Restoration of the previous aesthetic appearance before trauma.

For this, the treatment algorithm that we propose for fractures of the anterior table are set out in figure 3. The fractures of the anterior table that are linear, and that do not involve the nasofrontal duct, can be managed without surgical intervention. This nasofrontal mediante la utilización de un tubo de drenaje de material plástico, que ha de dejarse durante un mínimo de 30 o 40 días. ${ }^{7}$ Sin embargo, utilizando esta técnica se han descrito hasta un $30 \%$ de fallos por estenosis del conducto nasofrontal. ${ }^{11}$ Por otra parte, en nuestra experiencia, tanto los pacientes con sinusitis frontales de repetición como los que desarrollaron mucoceles se habían tratado de forma menos exhaustiva en la primera cirugía, pero tras desarrollar sus complicaciones y optarse por la obliteración del seno evolucionaron favorablemente (Fig. 5). Asimismo, no observamos complicaciones de este tipo en pacientes en los que se realizó obliteración como primer tratamiento.

Si la fractura de la pared anterior está desplazada y no se sospecha lesión del conducto, debe reducirse y fijarse, complementando con injertos óseos si fuese necesario. Pero si se sospecha lesión del conducto, es necesario completar el tratamiento con oblitera- was done with the slightly displaced fracture cases, where the expected aesthetic sequelae were minimal, and with patients that elected this attitude. When a lesion of the nasofrontal duct is suspected, obliterating the duct and sinus may be opted for, or an attempt may be made to leave it functioning by re-establishing patency. When obliterating the frontal sinuses, draining absolutely all the mucosa from these fragments is fundamental before reducing and fixing the bone fragments, duct and sinus. Drilling the sinus walls is recommended in order to eliminate the mucosa that may have remained in the Breschet's vascular pits. Different materials have been proposed for obliteration with satisfactory results, autologous ${ }^{10}$ as well as synthetic. Among the autologous materials (fat, muscle, bone), calvarial bone chip (Fig. 4) has advantages as it is easy to obtain. It can be combined 
ción de conducto y seno o tutorización del conducto.

En el tratamiento de las fracturas de la pared anterior del seno frontal es importante mencionar que el abordaje coronal clásico puede sustituirse en determinados casos por el endoscópico. En el momento actual su utilidad está reconocida para el tratamiento de las fracturas de pared anterior de seno frontal no conminutas, ${ }^{12}$ ya que en manos entrenadas puede reducir el tiempo de quirófano, así como disminuir la agresividad de la intervención y mejorar el postoperatorio.

Respecto a las fracturas que afectan a la pared posterior, el algoritmo terapéutico propuesto se esquematiza en la figura 6 . En aquellas fracturas lineales en las que no hay fístula de LCR la actitud puede ser conservadora, reevaluando la persistencia de dicha fístula al cabo de unos días, de lo contrario puede optarse por el tratamiento quirúrgico. Cuando son fracturas desplazadas y conminutas, lo ideal es cranealizar el seno tras eliminar completamente los fragmentos de pared posterior, reparar los defectos durales (mediante sutura directa o parches de duramadre), obliterar los conductos nasofrontales y sellar la fosa craneal anterior con colgajo de gálea-pericráneo (Fig. 7). Con ello se intenta aislar el espacio intracraneal para evitar la aparición de fístulas de líquido cefalorraquídeo y el desarrollo de posibles complicaciones infecciosas. En el tratamiento de este tipo de fracturas se puede utilizar el abordaje subcraneal descrito por Raveh. ${ }^{13}$ En este abordaje se utiliza una craneotomía frontal más reducida sobre el seno frontal que otros abordajes neuroquirúrgicos clásicos bifrontales, ${ }^{14}$ y subfrontales, ${ }^{15}$ que se puede ampliar hasta incluir parte de los techos orbitarios, las paredes orbitarias laterales, la glabela y los huesos nasales. Esta craneotomía permite el control del

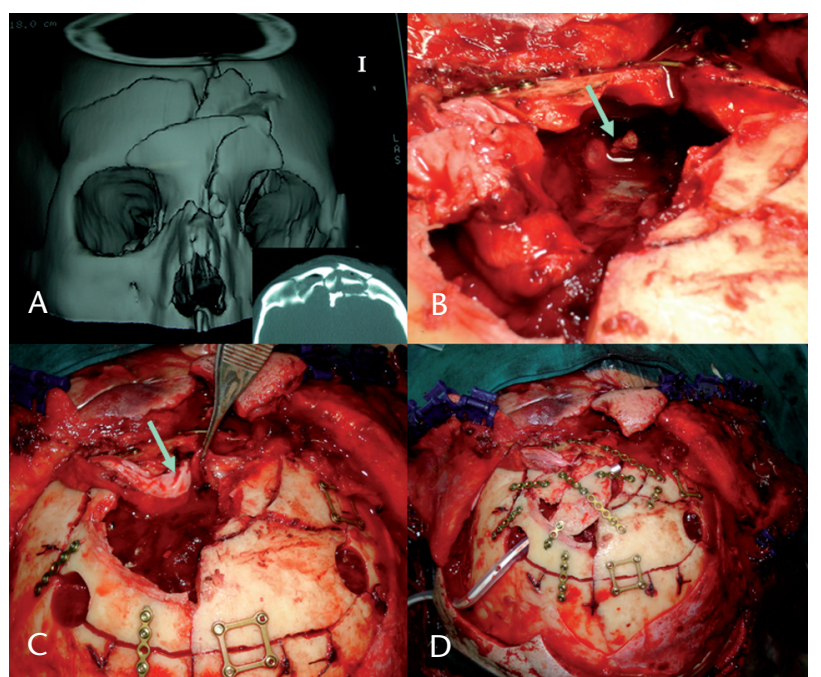

Figura 7. Mujer de 55 años con fractura conminuta bilateral de pared anterior y posterior de ambos senos frontales que se le realizó cranealización de dichos senos, obturación de conductos nasofrontales y reconstrucción de las paredes anteriores: A) TC prequirúrgica; B) obturación de conducto nasofrontal izquierdo (flecha); C) colgajo de gálea-pericráneo (flecha); D) reconstrucción final.

Figure 7. Female, 55 years old, with bilateral comminuted fractures of the anterior and posterior tables in both sinuses who underwent cranialization of these sinuses, obturation of the nasofrontal duct and reconstruction of the anterior tables: A) presurgical CT scan; B) obturation of the left nasofrontal duct (arrow); C) galeopericranial flap (arrow); D) final reconstruction. suelo de la fosa craneal anterior y duramadre frontal desde una aproximación basal, sin necesidad de retracción de los lóbulos frontales. Esto condiciona menor edema cerebral y permite tratar de forma precoz lesiones neuroquirúrgicas y fracturas craneofaciales asociadas. with other alloplastic material and it allows suitable follow-up by CAT scan, because it appears as bone density in the radiological image, which facilitates early detection of complications such as mucoceles, fistulas or abscesses. Some authors support preserving the function of the sinus, with the aim of minimizing the incidence of infectious complications. For this they resort to re-establishing patency of the nasofrontal duct by leaving in place, for a minimum period of 30 or 40 days, a drainage tube of plastic material. ${ }^{7}$ However, a 30\% failure rate has been described with this technique as a result of stenosis of the nasofrontal duct. ${ }^{11}$ On the other hand, our experience was that both the patients with recurrent frontal sinusitis and those who developed mucoceles and whose initial surgery was less exhaustive, evolved favorably (Fig. 5) when, following complications, obliteration of the sinus was carried out. Moreover, complications of this type were not observed in patients whose initial treatment included obliteration.

If the fracture of the anterior table is displaced, and if damage to the duct is not suspected, it should be reduced and fixed, and bone grafts should be added if necessary. But if damage to the duct is suspected, the treatment should be completed with obliteration of the duct and sinus, or patency of the duct should be established. 
Si las fracturas de pared posterior no son conminutas puede realizarse reducción de la fractura de pared posterior y osteosíntesis (Fig. 8), lo que también ha sido propuesto por Yavuzer. ${ }^{16}$ En caso de asociar una lesión del conducto nasofrontal, se puede completar con obliteración del seno u optar por cranealizarlo. Una actitud similar se puede tomar en casos fracturas no conminutas con fístula de LCR.

\section{Conclusiones}

El objetivo principal en la elección del tratamiento ideal para un paciente con una fractura de seno frontal ha de ser prevenir las complicaciones asociadas a corto y largo plazo. Para ello, es imprescindible realizar un diagnóstico clínico-radiológico preciso, así como un seguimiento a largo plazo, puesto que las complicaciones pueden aparecer tardíamente. El algoritmo de tratamiento propuesto debe ser individualizado en cada caso, atendiendo a características concretas de cada paciente, así como a la experiencia del cirujano.

La reducción y osteosíntesis de fracturas de pared posterior, completadas si es preciso con obliteración de conducto nasofrontal y seno, se presenta como una alternativa válida a la cranealización.

\section{Bibliografía}

1. Haugh RH, Likavec MJ. Frontal sinus reconstruction. Oral Maxillofac Surg Clin North Am 1994;2:65-83.

2. Rohrich RJ, Hollier $\mathrm{L}$. The role of nasofrontal duct in frontal sinus fracture management. J Craniomaxillofac Trauma 1996;2:31-40.

3. Sánchez Aniceto G. Estudio clínico epidemiológico de los traumatismos faciales en los accidentes de tráfico. Tesis doctoral. Universidad Complutense de Madrid, 1993.

4. Rohrich RJ, Hollier LH. Management of frontal sinus fractures, changing concepts. Clin Plast Surg 1992;19:219-32.

5. Manolidis S. Frontal sinus injuries: associated injuries and surgical management of 93 patients. J Oral Maxillofac Surg 2004;62:882-91.

6. Donald PJ, Berstein L. Compound frontal sinus injuries with intracranial penetration. Laryngoscope 1972;88:225-32.

7. Gervino G, Roccia F, Benech A, y cols. Analysis of 158 frontal sinus fractures: current surgical management and complications. I Craniomaxillofac Surg 2000;28:133-9.

8. El Khatib K, Danino A, Malka G. The frontal sinus: a culprit or a victim? A review of 40 cases. J Craniomaxillofac Surg 2004;32:314-7.

9. Ioannides $C$, Freihofer HP, Friens J. Fractures of the frontal sinus: a rationale of treatment. Br J Plast Surg 1993;46:208-4.
When treating fractures of the anterior table of the frontal sinus, it is important to mention that the classical coronal approach may be substituted in certain cases by the endoscopic approach. The usefulness of this approach is currently recognized for treating fractures of the anterior table of the frontal sinus that are not comminuted ${ }^{12}$ as, in trained hands, surgery time may be reduced, as well the aggressiveness of the intervention, and the postoperative period may improve.

With regard to fractures that affect the posterior table, the therapeutic algorithm that we propose is set out in figure 6. In linear fractures with no CSF fistula, a conservative approach may be taken, and the fistula can be reevaluated for persistence after a few days. Otherwise surgical treatment can be chosen. When the fractures are displaced and comminuted, the sinus ideally should be cranialized in order to eliminate the fragments of the posterior table completely. Defects to the dura should be repaired (by means of direct suturing or duramater patch), the nasofrontal ducts should be obliterated and the anterior cranial fossa should be sealed with a galeopericranial flap (Fig. 7). This is in order to attempt to isolate the intracranial space so that the appearance of CSF liquid fistulas and the development of possible infectious complications are avoided. In the treatment of this type of fractures the subcranial approach can be used as described by Raveh. ${ }^{13}$ In this approach a more reduced frontal craniotomy is used on the frontal sinus than the classical bifrontal ${ }^{14}$ and subfrontal ${ }^{15}$ neurosurgical approaches that can be extended to include part of the orbital roofs, the lateral orbital walls, the glabella and the nasal bones. This craniotomy permits controlling the anterior cranial fossa and frontal duramater using a basal approach, without the need for retracting the frontal lobes. This leads to reduced cerebral edema and any neurosurgical lesions and associated craniofacial fractures can be treated promptly.

If the fractures of the posterior table are not comminuted, the fracture of the posterior table can be reduced and osteosynthesis carried out (Fig. 8), also proposed by Yavuzer. ${ }^{16}$ If the lesion is associated with the nasofrontal duct, obliteration of the sinus can also be carried out or cranialization. A similar approach can be taken with fractures with a CSF fistula that are not comminuted. 
10. Rohrich RJ, Micel TJ. Frontal sinus obliteration: in search of the ideal autogenous material. Plast Reconstr Surg 1995;95:580-5.

11. Wilson BC, Davidson B, Corey JP, Haydon RC. Comparison of complications following frontal sinus fractures managed with or without obliteration over 10 years. Laryngoscope 1988;98:516-20.

12. Schön R, Gellrich NC, Schmelzeisen R. Frontiers in maxillofacial endoscopic surgery. Oral Maxillofac Surg Clin North Am 2003;11:209-38.

13. Raveh J, Laedrach K, Vuiltemin T, Zing M. Management of combined frontonaso-orbital/skull base fractures and telecanthus in 355 cases. Arch Otolaryngol Head Neck Surg 1992;118:605-14.

14. Derome P. Les tumeurs sphénoethmoïdales. Possibilités d'exérèse et de réparation chirurgicales. Neurochirurgie 1972;18(Supl 1):1-164.

15. Sekhar LN, Nanda A, Sen CN, Snyderman CN, Janecka IP. The extended frontal approach to tumors of the anterior, middle, and posterior skull base. I Neurosurg 1992;76:198-206.

16. Yavuzer R, Sari A, Kelly CP, Tuncer S, Latifoglu O, Celebi C, Jackson IT. Management of frontal sins fractures. Plast Reconstr Surg 2005;115:79-93.

\section{Conclusion}

The principal objective when choosing the treatment best suited for a patient with a frontal sinus fracture has to be the prevention of associated short-term or long-term complications. For this, carrying out a precise clinical-radiological diagnosis is essential, as is a long-term follow-up, as there may be late complications.

The treatment algorithm proposed should be individualized in each case, and the particular characteristics of each patient should be taken into account, as should the experience of the surgeon.

The reduction and osteosynthesis of posterior table fractures, with additional obliteration of the nasofrontal duct if necessary, is presented as a valid alternative to cranialization. 